Rev. Edward Sienkiewicz

University of Szczecin

DOI: $10.15290 /$ rtk.2020.19.05

iD 0000-0002-6711-9933

\title{
Scientia Fidei - Science or Life?
}

A particular aspect of theological knowledge, which arises from the intellectual search based on faith, is the exceptionally favorable opportunity it provides to overcome the antimonies of science and life. After all, theology not only engages reason and faith but also the will and love. On this basis, scientia fidei (science of faith) claims to make sense of everything, meaning of wisdom, at the center of which can be found truth and life, which both accord with it. Moreover, any systematic reflection on faith should take place within specific context that is understood as its basic challenge. This does not mean that it is possible to evaluate or correct the faith according to so-called "life experience", but rather that life can be ordered according to faith. In other words, any interest in human agere (act) should not lose sight of esse (being). From this point of view, science of faith should not only resolve the tension between rational knowing and mystery, but also protect against one-sidedness and superficiality through competent and particular knowledge that defines who man is and determines how he should act. A utilitarian approach to empirical science as well as contemporary philosophy, which does not consider wisdom and the question of truth, is incompetence in this regard.

Key words: knowledge, faith, science, truth, love, knowing, reason, practice, philosophy.

Only ostensibly does one understand the question presented in the title of the article as a probing search for the answers to the questions: "What should we do with what we have learned? What have we been able to investigate and come to know through reason? What have we come to see, hear, and believe, even if our knowledge and faith are disproportionate to each other?" In reality, this process is neither that straightforward nor simple as is treating question posed in the title of this article as an insurmountable dilemma. At this point, without 
coming to a premature conclusions regarding whether the dilemma is real or a merely artificial mental construct (with its own causes and effects, of course), it is worthwhile to remember that theology's "value is confirmed in its task (mission) to save peoples and nations."

Such an approach makes it possible to distinguish four basic questions that must be addressed in order to resolve this problem. The first question concerns the particular character of theological knowledge or science of faith. The second question involves the human will, which acts according to knowledge (reason). The third issue is verifying the intellectual quest to understand the faith. ${ }^{2}$ And, finally, the fourth question concerns its proper "role" in shaping the Christian Credo (belief). Each of these dimensions shares the fundamental issue of truth, which is the science that verifies and defines. ${ }^{3}$ At the same time, every context in which faith is considered and reflected upon is no less essential and serves as a basic reference. ${ }^{4}$

\section{Theology as Certain Knowledge}

Even if we were to define theology according to St. Bonaventure as certain knowledge that flows from love and simultaneously an invitation to love ${ }^{5}$ theology--like each type of knowledge-is based on reason. Theology's uniqueness among the other fields of human knowledge and science does not arise only from love; for, faith is

1 J. Szymik, O teologii dzisiaj. Zadania, piękno, przyszłość, Pelplin 2006, 91.

2 B. Ferdek, "Światło wiary w obliczu światła rozumu," in: Problem kulturoworeligijnej reinterpretacji wspótczesnej Europy, ed. J. Moskałyk, Poznań 2019, 139.

J. Ratzinger, "Rozumienie objawienia i teologia historii według Bonawentury. Rozprawa habilitacyjna i studia nad Bonawenturą," in: Opera Omnia, vol. 2, trans. J. Merecki, ed. K. Góźdź, M. Górecka, Lublin 2014, 335-337.

B. Häring, Siła i stabość religii. Socjologia religii jako wyzwanie, trans. J. Klenowski, Poznań 1966; K. Rahner, Podstawowy wykład wiary. Wprowadzenie do pojęcia chrześcijaństwa, trans. T. Mieszkowski, Warszawa 1987, 325-332; H. Waldenfels, O Bogu, Jezusie Chrystusie i Kościele - dzisiaj. Teologia fundamentalna w kontekście czasów obecnych, trans. A. Paciorek, Katowice 1993; H. U. von Balthasar, Teodramatyka, 1 Prolegomena, trans. M. Mijalska, M. Rodkiewicz, W. Szymona, Kraków 2005, 13-80, 119-240; G. L. Müller, Raport o stanie nadziei. Rozmowa z Carlosem Granadosem, trans. K. Jasiński, Warszawa 2018; J. Szymik, O teologii dzisiaj, 45-46; R. Kuligowski, "Jak żyć wiarą?," in: Perspektywy wiary, ed. M. Jagodziński, Radom 2015, 128; J. Wojtkun, "Lumen fidei $i$ Veritatis splendor - światto wiary w blasku prawdy moralnej," in: Perspektywy wiary, ed. M. Jagodziński, Radom 2015, 144-148. 
another element that is necessary and particular to theology. Hence, postulating love ${ }^{6}$ and human reason, theology can be defined as the enterprise arising from faith that strives to understand the content of faith. Theological reflection must be carried out using rational and well-founded principles and logical methods, which are invaluable for man to achieve certainty that his "action," meaning his conditioned knowledge, is true. ${ }^{7}$

At least one thing has been verified here, since science is concerned with truth! The science of theology, however, is central since it is concerned with knowing God. Because God is the Subject with which theology is concerned, Misterium-or the dimension that intellectual seeking for truth cannot penetrate freely because it is unable to do so-also lies at the heart of theology. ${ }^{8}$ In this situation, a rather clear tension arises between striving to understand faith and the mystery that is integral to this search. In addition to this tension, there is the temptation to overcome it as quickly as possible. One way that people seek to relieve this tension is to shift the search of faith that seeks to understand its own content and come to knowledge of the truth excessively toward either rationalism or fideism. This shift, however, simply disturbs what lies at the core of theology: Truth and Mystery. This disturbance is a major shock to theology itself. So what should be done when the tension becomes unbearable? And what does this mean for theology as a systematic examination of faith? This tension can be dealt with through the "particular character" of theology as a science in which humility and courage are just as important as intellectual knowledge due to the Subject of theological knowledge and the conditions by which this Subject comes to be known. Thus, returning once again to Bonaventure, love is very much necessary so that pride will not dominate humility, on the one hand, and so that one will not lose courage and thus withdraw from the intellectual search, on the other. In both cases, this means that it is necessary persevere in the difficult tension, which is the theologian's mission and task.

Within this tension, which entails choosing to reject the delusion that "there is an easier path to the truth" (i.e., shortcut) through

6 Congregation for the Doctrine of the Faith, Instruction Donum Veritatis on the Ecclesial Vocation of the Theologian, May 24, 1990. http:// www.vatican.va/roman_curia/congregations/cfaith/documents/ rc_con_cfaith_doc_19900524_theologian-vocation_en.html.

7 J. Ratzinger, "Wiara w Piśmie i Tradycji. Teologiczna nauka o zasadach," in: Opera Omnia, vol. 9/1, trans. J. Merecki, eds. K. Góźdź, M. Górecka, Lublin 2018, 159, 304.

$8 \quad$ Ibid., 323. 
Dogmatic Theology

utilitarianism or partialism, both love and reason are important ${ }^{9}$ - the ability to love and submit subject it to rational judgment. According to Richard of St. Victoria and Joseph Ratzinger, who drew on the writings of St. Bonaventure and Pseudo-Dionysius, in this instance love is a "particular eye" that is endowed with the penetrating power to see. ${ }^{10}$ This reveals not only theology's credibility and its real achievements, but also the lack of conflict between reason and faith as well as knowledge and love. On the other hand, it does determine their congruity, cooperation, and support-how they interact and mutually complement each other. This entails not only theoretical knowledge but - even more - the information that one has obtained. This concerns a spiritual attitude and the life that results from it-a life marked by the special "touch of love," due to which we can begin to identify our existence with known truth, which is expressed by theological knowing. This, however, certainly does not entail an attempt to revise the faith based on one's experience, even if one has judged his life to be very happy. We will return to this point later.

\section{The Temptation to Revise Knowledge Based on Life}

Attempts to verify or even alter the faith due to intellectual knowledge gained through life experience in one way or another have been made for years. Moreover, numerous authors have proclaimed these attempts successful and very promising. In this long and complex history, one experience stands out as epochal-namely, the Marxist appreciation of revolutionary praxis. ${ }^{11}$ This endeavor involved the practical implementation of philosophy, ${ }^{12}$ which occurred on such a massive scale for the first time in history.

Of course, this is not to prejudge the Marxist character of utilitarianism that is so common in learning and human knowledge today. Moreover, Karl Marx's conclusion is neither the final nor most influential "appreciation of the practical dimension that comes at the expense of theory" or so-called "life at the expense of knowledge." As it turns out, the history of attempts to give priority to the practical assessment of cognitive abilities is long and complex and something to which the

$9 \quad$ J. Ratzinger, "O nauczaniu II Soboru Watykańskiego," in: Opera Omnia, vol. 7/2, trans. E. Grzesiuk, eds. K. Góźdź, M. Górecka, Lublin 2016, 694.

$10 \quad$ Ibid., 694.

11 W. Roszkowski, Roztrzaskane lustro. Upadek cywilizacji zachodniej, Kraków 2019, 83-85.

12 K. Marks, Tezy o Feuerbachu, in: idem, Dzieła, vol. 3, Warszawa 1961, 25. 
field of theology cannot remain indifferent. ${ }^{13}$ For, this process began with the ancient Greeks' practical treatment of the love of wisdom (filosofia) to attain a happy life. It was then manifest in the ancient Greeks' discovery of the natural law ${ }^{14}$ and the distinctions that they made between nomos and logos and physis. ${ }^{15}$ Modern science's preoccupation with facts while disregarding how they are connected as well as its refusal to treat philosophy as the field of study that pursues truth and, instead, regard it merely as a useful tool. With time, the concept of "natural law" was replaced by the plural expression "laws of nature," which alter how "natural law" had been heretofore understood. Finally this led to the reduction of science to that which could be verified by experience (confirmed in practice) to the point that fields of knowledge that cannot be verified in this manner were arbitrarily discredited. ${ }^{16}$

Needless to say, there are other moments and events in history that occurred, not all of which were clearly opposed to science itself, that have challenge theology to such an extent that, in our present day, the sciences that are able to reproduce their results in practice as soon as possible are shown preference and given priority. It is no particular surprise, then, that the field of theology has been marginalized, and modern science preempts the question of truth. This does not mean, however, that theologians are excused from participating in contemporary discussions and disputes about the truth or, even more, be resigned to its gradual marginalization!

\section{Faith and Life in the History of Theology}

In the history of theology, Antonius (of Florence) Pierrozi (13891459) was the first theologian in the practical sense. Pierrozi sought to order the Christian life according to divine law. The following Spanish theologians Rodrigo Sánchez de Arévalo (1405-1470) and Juan

$13 \quad$ P. Kiejkowski, “Trzy słowa papieża Benedykta XVI dla Europy. W trosce o integralny humanizm," in:Problem kulturowo-religijnejreinterpretacji wspótczesnej Europy, ed. J. Moskałyk, Poznań 2019, 94.

14 R. Brague, Prawo Boga. Filozoficzna historia przymierza, trans. M. Wodzyńska, A. Kocot, Warszawa 2014, 43-44, 48-69.

15 J.-P. Vernant, Źródta myśli greckiej, trans. J. Szacki, Gdańsk 1996, 2, 4, 47, 63, 84, 102; Pseudo-Platon, Zimorodek $i$ inne dialogi, trans. L. Regner, Warszawa 1985, 317 d. 321 bc; Ksenofont z Efezu, Pisma sokratyczne, trans. L. Joachimowicz, Warszawa 1967, I, 2, 42.R.

$16 \quad$ F. Oakley, "Christian Theology and the Newtonian Science. The Rise of the Concept of the Laws of Nature," Church History 30(1961): 433-457. 
Dogmatic Theology
Torquemada (1388-1468) also followed suit. ${ }^{17}$ However, this historical understanding of theology does not need to be tied to the investigations of systematic theologians who are interested in the relationship between faith and life. The first Christian writers and apologists, who valued historical arguments, occupy an important place in this type of theology ${ }^{18}$ However, Sacred Scripture, which presents God as "active" in his creation and the redemption of $\operatorname{man}^{19}$ and to which the New Testament belongs - the books in which Jesus proclaims that the Kingdom of God is at hand and Himself goes before those who believe in Him on the path of salvation and preserves their life (Jn 8:51)—holds primacy of place. Rightly, then, Joseph Ratzinger asserts: "Indeed, reading the Bible leaves no doubt regarding the practical nature of faith in Almighty God."20

A particular retrospection is necessary when considering the conclusions that some historians of theology have drawn. For example, when defending the scholarship and sagacity of Christians, St. Justin emphasized orthos and nomos in addition to logos. Clement of Alexandria, on the other hand, asserted in Stromata (1.38) that knowledge is dependent on God's will, which comes to be known by "doing the will of God." "21 In turn, Anselm acknowledges the role of experience in coming to know truth. ${ }^{22}$ Bonaventure defined theology as scientia et sapientia and happiness as the result of the synthesis of the mind and action, faith and life. Among these thinkers, one cannot forget the medieval philosopher Duns Scotus' and his concept of voluntarism, according to which God creates the world because he wills, and his will is not limited by anything. Finally, William Ockham understood theology as learning "in another sense." According to Ockham, theology is above other fields of knowledge and belongs to the order of

17

T. M. Izbicki, Protector of the Faith. Cardinal Johannes de Turrecremata and the Defense of Institutional Church, Washington 1981, 269, 293-294; R. H. Trame, Rodrigo Sáncheza de Arévalo. Spanish dyplomat and champion of Papacy, Washington 1958.

J.H. Newman, Orozwoju doktryny chrześcijańskiej, trans. J.Zielińska, Warszawa 2000, 328-330; H. U. von Balthasar, Teodramatyka, 2 Osoba dramatu, cz. 1, Człowiek w Bogu, trans. W. Szymona, Kraków 2006, 126-141.

Benedykt XVI, "Fundamentem prawdziwej kultury jest poszukiwanie Boga," L'Osservatore Romano, Polish Edition, 10-11(2008): 16.

J. Ratzinger, Wiara w Piśmie i Tradycji, 43.

A. di Berardino, B. Studer, eds., Historia Teologii, vol. 1: Epoka patrystyczna, Kraków 2003, 163-164. 
wisdom; thus, theology's relationship to life is as obvious as the facts that concern the other sciences. ${ }^{23}$

The practical and existential dimension of knowledge was strengthened in the philosophy of Immanuel Kant, among others..$^{24}$ In addition, in the $17^{\text {th }}$ century, moral theology, which was known as practical theology and separated from scholastic theology. ${ }^{25}$ Moreover, Protestantism played a very important role in the development of theology; for, in referring to "personal experience," Protestantism greatly diminished the significance of reason and free will. ${ }^{26}$

\section{Revising Practical Reason Based on Faith}

Keeping in mind the above, we will try to determine how theology is related to life, by avoiding artificial or reductionist approaches that contrasting theory and practice or even separate them. Faith cannot be reduced only to knowledge, and one cannot forgo the question of truth. ${ }^{27}$ In this sense, theology as a specific spiritual approach (based on faith) from which choices flow is the proper understanding of the roles that human reason, revelation, and life play in events. This means the cooperation of man's reason and free will. ${ }^{28}$ On this basis, the discovery of meaning becomes essential and theology's primal question in its relationship to life. As has been said: "theology is concerned with you." 29 Theology as a field of knowledge that is applied at every stage to real life is concerned with ensuring that Jesus is present in his death on the cross in every human suffering, failure, encounter, or descent into death. It is also concerned with the fact that the risen Christ is present in every human victory, joy, and (despite the terror of death) conviction that death is not the end of everything but rather

${ }_{23}$ G. D’Onofrio, Historia Teologii, vol. 2: Epoka średniowieczna, Kraków 2005, 179-180; 364-368; 487-488; 490-491; 523-526.

A. M. Kaniowski, "Filozofia praktyczna Immanuela Kanta - jej siła i słabości," Diametros 2(2004): 114-126.

F. D. Osuna, Tercer Abecedario Espirytual, Madrid 1972, 140-149.

M. D. Chenu, Wybór pism, trans. L. Rutkowska, W. Sukiennicka, Z. Włodkowa, Warszawa 1971, 228-246.

K. Rahner, Praxis des Glaubens. Geistliches Lesebuch, Freiburg-Basel-Wien 1984, 52-199.

K. Rahner, Pisma wybrane, vol. 1, trans. G. Bubel, Kraków 2005, 168-180, 242-243.

T. Węcławski, W teologii chodzi o ciebie. Przewodnik po źródłach i skutkach reologicznej wyobraźni, Kraków 1995; T. Halik, Co nie jest chwiejne. Labiryntem świata z wiara i wątpliwościami, trans. J. Zychowicz, Kraków 2004, 94-95; H. U. von Balthasar, Teodramatyka, 1 Prolegomena, 15-22. 
the beginning of something that is better, more important, and more beautiful than anything in this life.

In uncovering the deep meaning of human existence, theology as knowledge cannot afford to downplay the climactic moment in the New Testament when the dispute over truth takes place-namely, in Pilate's praetorium when Jesus says: "For this I was born and for this I came into the world, to testify to the truth" (Jn 18:37). In this place and from this moment on, truth ceases to be the domain of philosophers; instead, it enters into the domain of theology and becomes the foundation of life! Rejecting truth means rejecting Jesus and eliminating Christianity. Conversely, proclaiming Jesus, his presence, and the fact that he is everything in response to the most difficult existential questions necessitates the objective and binding (to all) character of the truth. ${ }^{30}$ It is for this reason that the words from John's Gospel: "I am the way, the truth, and the life" (14:6) are the most accurate and synthetic description of the relationship between theology and life.

\section{A Love that Orders the Relationship Between Faith and Life}

As stated earlier, theology acknowledges that every person needs to be loved. For this reason, theology' should aim to define what love truly is and is not. ${ }^{31}$ In this regard, Augustine's attempted to arrive caritas by means of cupiditas and even amor-both of which proved not to truly fulfill him. ${ }^{32}$ When determining what love is and is not, the words contained in Paul's Letter to the Romans "love is the fulfillment of the law" (Rom 13:10) are quite helpful. In the New Testament, theology and its relationship to life are at stake in Jesus' dispute with the Pharisees regarding the interpretation of the law. This dispute involves love and truth. ${ }^{33}$ The Pharisees wanted to be obedient to the law, but they did not necessarily see the need for charity. In addition,

30 P. Nitecki, "Quod est veritas. Spotkanie z Jezusem w pretorium Piłata," Życie i Myśl 25(2009): 74; J. A. Allen, Irreligion. A Mathematician Explains Why the Arguments for God Just Don't App Up, New York 2009.

31 R. Laurentin, Nowe wymiary miłości, trans. M. Bocheńska, Warszawa 1977, 5-36; A. Andrzejuk, "Franciszek Sawicki: Filozofia miłości," in: A. Andrzejuk, Metafizyka obecności. Wstęp do teorii relacjiosobowych, Warszawa 2012,343-344.

32 Augustyn, Solilokwia, I, 1, trans. A. Świderkówna, in: Dialogi filozoficzne, Kraków 1999; Idem, Państwo Boże, trans. W. Kubicki, Kęty 1998, 11, 9, 10; Idem, O Trójcy Świętej, trans. Stokowska, Kraków 1996, 15, 28, 51.

$33 \quad$ H. Merklein, Jesu Botschaftvon der Gottesherrschaft, Stuttgart 1983, 93; R. Brague, La Sagesse du monde. Histoire de l'expérience humaine de l'univers, Paris 1999, 
they do not doubt that the law and love that are binding. Their lack of love, however, influences their interpretation of the law and truth. By involving love-by connecting it with the law and truth, Jesus, on the other hand, incorporates the law, which Paul interprets using the stoic concept of conscience. Therefore, love, which is expressed in the words "I have come not to abolish the law but to fulfill it" (Mt 5:17), is the most effective basis for law that is just and truth that binds. ${ }^{34}$

Love in this sense cannot be limited only to benevolence, but as caritas, meaning a gift (connected with a readiness to sacrifice and even suffer), it cannot be excused from benevolence either. Revealed truth about the Holy Trinity is the most basic case for this belief. This truth also makes it possible to define what love is not based on the expectations articulated above..$^{35}$ The relationship of love between the Divine Persons cannot be considered merely theoretically or claim to separate theology from actual Christian life. Benedict XVI shows this very well in his encyclical Deus Caritas Est, where he quotes St. Augustine: "If you see charity, you see the Trinity."” 36 This short sentence could be arranged so that the converse is also true: namely, only in the truth about the Trinity can one come to know what love is! It can be defined as seeking after the truth in the same direction, because it is difficult to deny that many people want to reach the truth in different ways. God's weakness is His strength, and His love is the most beautiful revelation about Him.

At this point it is worthwhile to refer to the first point made in this article, where I we establish that a complete image of Truth needs knowledge and love, and which serve each other. The truth is beautiful and great because it encompasses knowledge and love. Both activities are indispensible. Both serve the truth and, through the truth, are defined and make sense, thus creating a trithestic image! Just like theology, knowledge is beautiful and important because, as such, it orders life—or at least it should—and, in this way, becomes wisdom.

201-202; R. P. Booth, Jesus and the Laws of Purity: Tradition History and Legal History in Mark 7, Trowbridge 1986, 219.

34 T. Kazen, "Jesus, Scripture and Paradosis: Response to Friedrich Avemarie," in: The New Testament and Rabbinic Literature, eds. R. Biringer, F. G. Martinez, D. Pllefeyt, P. J. Tomson, Boston-Leiden 2010, 288.

35 J.Daniélou, Trójca Święta i tajemnica egzystencji.Znaki świątyni czyliobecności Boga, trans. M. Tarnowska, Kraków 1994, 53-60; G. Greshake, Wierzę w Boga Trójjedynego. Klucz do zrozumienia Trójcy Świętej, trans. W. Szymona, Kraków 2001. 


\section{Theology as Wisdom}

Just as the claim that science and life are opposed to each other is absurd, individuals also attempt to oppose knowledge and wisdom. Theology was called "certain knowledge" because, when understood and developed properly, it avoids partiality and, thereby, conflict with other fields of knowledge and claims to make sense of everything. In other words, wisdom not only asks how one should live, but it also provides the answer to this question." 37

Just like the practical dimension of theology, the wise dimension undoubtedly teaches everyone to be deeply humble as well as something that philosophy lost long ago. ${ }^{38}$ Only a well-understood and developed theology can interpret the complex reality that the Bible presents. Judaic thought was unable to handle this reality and tried to impose too much unity on the Bible. Like ancient Greek thought, Judaic thought was too attached to dualism; theory and practice, faith and life, and knowledge and wisdom are manifestations of this complexity. They indicate the way that leads to reconciliation with oneself and, in Jesus Christ, to union between "the world of God" and the "world of man." Certainly, theology in no way separates these things from each other or, even worse, opposes them like faith and life as well as knowledge and wisdom used to be.

In this image of "fullness," the ancient Greek means to happiness, meaning philosophy (love of wisdom) seems insufficient. All the more, philosophy seems "defective," and loses its character as wise and interested in the truth (insofar as it remains philosophy). One cannot completely depart from philosophy, but rather, demonstrating how it is useful, one must also realize that it is insufficient ${ }^{39}$ in encountering the great challenge that what one encounters in, for example, fear of death in the face of meaning and life. Philosophy does not deal with this kind of fear. Rather, only "sufficient" wisdom is able to deal with such existential fear. It does not cower before the threat of death and does not give into the temptation to despair because they are insurmountable and cast a shadow on all of man's achievements, including his knowledge of truth and his love, on his faith and on his life.

37 Być dla, czyli myśleć sercem. Z ks. biskupem A. Nossolem rozmawia ks. J. Szymik, Katowice 1999, 72, 94, 130.

38 J. Paszyński, Eudajmonizm, vol. 3, Lublin 2002, 306-307.

39 M. Urban, "Hans Urs von Balthasar - otwarty rozum," in: H. U. von Balthasar, Pisma wybrane, vol. 1: Pisma filozoficzne, trans. M. Urban, D. Jankowska, Kraków 2006, 9-12. 
True wisdom is manifested in knowing and loving: in learning and living. This means that wisdom needs knowledge and holiness, ${ }^{40}$ which, according to St. Benedict of Nursia, are attained through contemplation and good works-ora et labora. Throughout the ages, Christian culture and Europe have been shaped by the rule of St. Benedict. To this culture belongs, among other things, very practical solutions that serve as the foundations for trade and the economy in every culture. The first monasteries in the West were also the first to implement these functions, and they prospered because they were-according to today's understanding - well-managed firms. ${ }^{41}$ Scientia fidei should be not only "discursive" and "prayerful," 42 but also (and in the truly Benedictine sense) "active" and correspond to permeate human life it in order to shape and develop it based on faith. For, faith cannot be altered or in any way shaped by life, but rather the reverse: faith should shape life.

\section{Conclusion}

The attempt to describe how theology and life are related to each other should not omit two important issues: the specific life context and the need for meaning. This is the most fundamental challenge for theology. This challenge cannot be addressed using a utilitarian approach to the empirical sciences or of a philosophy that is too theoretical and unable to do so because it has lost its wisdom character and is no longer concerned with objective truth.

In order to "rescue peoples and nations," theology must take up this challenge, which actually determines its interests and permeates concrete human life. There are two reasons for this: first, theology is still concerned with knowledge. Scientia fidei does not permit faith to be altered by practical life. This faith must-as has been articulatedorder life. This text, therefore, is not devoid of systematic reflections that are often considered theoretical. Second, today the preference for the practical value of human knowledge-that is, agere-has gone so far that no one cares anymore about the complexity and richness as well as the beauty and delightful mystery of the human esse. Clearly, the expression "no one" does not refer to those who treat theology as the field concerned with knowledge and, more specifically, particular

\footnotetext{
$40 \quad$ A. Štrukelj, Teologia i świętość, trans. M. Jagodziński, Lublin 2010, 9-21.

41 A. Solignac, P. Massein, J. Gribomont, P. Miquel, J. Dubois, P. Riche, J. Becquet, K. F. Suso, D. Lunn, E. Behr-Sigel, E. Severus, Monastycyzm. Historia i duchowość, trans. D. Stanicka-Apostoł, Kraków 2002, 119-120. 
Dogmatic Theology

knowledge in the sense that theology is continually preoccupied with the search for truth, regardless of obstacles and consequences this search may present, because they are convinced about the necessity of a love that orders life based on faith and strengthens the intellectual search. Only knowledge that focuses on truth can remedy a revaluation that favors action - that is, praxis - as well as academic utilitarianism without considering the questions of truth or life without love. The revaluation of agere to the detriment of esse and vice versa as well as the choice to separate them are highly detrimental to both. The ability to both define who man is and what how he should act is necessary.

\section{Bibliography:}

1. Allen, J. A. Irreligion: A Mathematician Explains Why the Arguments for God Just Don't App Up. New York 2009.

2. Andrzejuk, A. "Franciszek Sawicki: Filozofia miłości." In: A. Andrzejuk. Metafizyka obecności. Wstęp do teorii relacji osobowych. Warszawa 2012, 343-358.

3. Augustyn. O Trójcy Świętej. Translated by M. Stokowska. Kraków 1996.

4. Augustyn. Państwo Boże. Translated by W. Kubicki. Kęty 1998.

5. Augustyn. "Solilokwia, I, 1." Translated by A. Świderkówna. In: Dialogi filozoficzne. Kraków 1999.

6. Balthasar, H. U. von. Teodramatyka, 1 Prolegomena. Translated by M. Mijalska, M. Rodkiewicz, W. Szymona. Kraków 2005.

7. Balthasar, H. U. von. Teodramatyka, 2 Osoba dramatu, cz. 1, Człowiek $w$ Bogu. Translated by W. Szymona. Kraków 2006.

8. Balthasar, H. U. von. Teologika, 2 Prawda Boga. Translated by J. Zychowicz. Kraków 2004.

9. Benedykt XVI. Deus caritas est. Watykan 2005.

10. Benedykt XVI. "Fundamentem prawdziwej kultury jest poszukiwanie Boga." L'Osservatore Romano, Polish Edition 10-11(2008).

11. Booth, R. P. Jesus and the Laws of Purity: Tradition History and Legal History in Mark 7. Trowbridge 1986.

12. Brague, R. La Sagesse du monde. Histoire de l'expérience humaine de l'univers. Paris 1999.

13. Brague, R. Prawo Boga. Filozoficzna historia przymierza. Translated by M. Wodzyńska, A. Kocot. Warszawa 2014.

14. Być dla, czyli myśleć sercem. Z ks. biskupem A. Nossolem rozmawia ks. J. Szymik. Katowice 1999.

15. Chenu, M. D. Wybór pism. Translated by L. Rutkowska, W. Sukiennicka, Z. Włodkowa. Warszawa 1971.

16. Congregation for the Doctrine of the Faith. Instruction Donum Veritatis on the Ecclesial Vocation of the Theologian. May 24, 1990. http://www.vatican.va/roman_curia/congregations/cfaith/documents/ rc_con_cfaith_doc_19900524_theologian-vocation_en.html. 
17. Daniélou, J. Trójca Święta i tajemnica egzystencji. Znaki świątyni czyli obecności Boga. Translated by M. Tarnowska. Kraków 1994.

18. Di Berardino, A., Studer, B., eds. Historia Teologii. Volume 1: Epoka patrystyczna. Kraków 2003.

19. D’Onofrio, G., ed. Historia Teologii. Volume 2: Epoka średniowieczna. Translated by W. Szymona. Kraków 2010.

20. Ferdek, B. "Światło wiary w obliczu światła rozumu." In: Problem kulturowo-religijnej reinterpretacji wspótczesnej Europy. Edited by J. Moskałyk. Poznań 2019, 137-148.

21. Greshake, G. Wierzę $w$ Boga Trójjedynego. Klucz do zrozumienia Trójcy Świętej. Translated by W. Szymona. Kraków 2001.

22. Halik, T. Co nie jest chwiejne. Labiryntem świata z wiara i watpliwościami. Translated by J. Zychowicz. Kraków 2004.

23. Häring, B. Sita i stabość religii. Socjologia religii jako wyzwanie. Translated by J. Klenowski. Poznań 1966.

24. Izbicki, T. M. Protector of the Faith. Cardinal Johannes de Turrecremata and the Defense of Institutional Church. Washington 1981.

25. Kaniowski, A. M. "Filozofia praktyczna Immanuela Kanta - jej siła i słabości." Diametros 2(2004): 114-126.

26. Kazen, T. "Jesus, Scripture and Paradosis: Response to Friedrich Avemarie.” In: The New Testament and Rabbinic Literature. Edited by R. Biringer, F. G. Martinez, D. Pllefeyt, P. J. Tomson. Boston-Leiden 2010.

27. Kiedio, E. "Być silnym, żeby być łagodnym, Z s. Małgorzatą Chmielewską rozmawia Ewa Kiedio." Więź LVI (2013). https://wiez. pl/2018/01/19/byc-silnym-zeby-byc-lagodnym-wywiad-z-s-malgorzatachmielewska/?fbclid=IwAR06yh_w3q581sM9_KlrLWZOu1d9xZnjhgLETZzBLbveiYUg8lcGiCNx19w

28. Kiejkowski, P. “Trzy słowa papieża Benedykta XVI dla Europy. W trosce o integralny humanizm." In: Problem kulturowo-religijnej reinterpretacji współczesnej Europy. Edited by J. Moskałyk. Poznań 2019, 89-106.

29. Ksenofont z Efezu. Pisma sokratyczne. Translated by L. Joachimowicz. Warszawa 1967.

30. Kuligowski, R. "Jak żyć wiarą?" In: Perspektywy wiary. Edited by M. Jagodziński. Radom 2015, 127-141.

31. Laurentin, R. Nowe wymiary miłości. Translated by M. Bocheńska. Warszawa 1977.

32. Marks, K. Tezy o Feuerbachu. In: K. Marks. Dzieła. Volume 3. Warszawa 1961.

33. Merklein, H. Jesu Botschaft von der Gottesherrschaft. Stuttgart 1983.

34. Morales, J. Wprowadzenie do teologii. Translated by P. Rak. Kraków 2006.

35. Müller, G. L. Raport o stanie nadziei. Rozmowa z Carlosem Granadosem. Translated by K. Jasiński. Warszawa 2018.

36. Newman, J. H. O rozwoju doktryny chrześcijańskiej. Translated by J. Zielińska. Warszawa 2000.

37. Nitecki, P. “Quod est veritas? Spotkanie z Jezusem w pretorium Piłata." Życie i Myśl 25(2009): 71-80. 
38. Oakley, F. "Christian Theology and the Newtonian Science. The Rise of the Concept of the Laws of Nature." Church History 30(1961): 433-457.

39. Osuna, F. D. Tercer Abecedario Espirytual. Madrid 1972.

40. Paszyński, J. Eudajmonizm. Volume 3. Lublin 2002.

41. Pseudo-Platon, Zimorodek $i$ inne dialogi. Translated by L. Regner. Warszawa 1985.

42. Rahner, K. Pisma wybrane. Volume 1. Translated by G. Bubel. Kraków 2005.

43. Rahner, K. Podstawowy wyktad wiary. Wprowadzenie do pojecia chrześcijaństwa. Translated by T. Mieszkowski. Warszawa 1987.

44. Rahner, K. Praxis des Glaubens. Geistliches Lesebuch. Freiburg-BaselWien 1984.

45. Ratzinger, J. “O nauczaniu II Soboru Watykańskiego.” In: Opera Omnia. Volume 7/2. Translated by E. Grzesiuk. Edited by K. Góźdź, M. Górecka. Lublin 2016.

46. Ratzinger, J. "Rozumienie objawienia i teologia historii według Bonawentury. Rozprawa habilitacyjna i studia nad Bonawenturą." In: Opera Omnia. Volume 2. Translated by J. Merecki. Edited by K. Góźdź, M. Górecka. Lublin 2014.

47. Ratzinger, J. "Wiara w Piśmie i Tradycji. Teologiczna nauka o zasadach." Translated by J. Merecki. In: Opera Omnia. Volume 9/1. Edited by K. Góźdź, M. Górecka. Lublin 2018.

48. Roszkowski, W. Roztrzaskane lustro. Upadek cywilizacji zachodniej. Kraków 2019.

49. Solignac, A., Massein, P., Gribomont, J., Miquel, P., Dubois, J., Riche, P., Becquet, J., Suso, K. F., Lunn, D., Behr-Sigel, E., Severus, E. Monastycyzm. Historia i duchowość. Translated by D. Stanicka-Apostoł. Kraków 2002.

50. Szymik, J. O teologii dzisiaj. Zadania, piękno, przyszłość. Pelplin 2006.

51. Štrukelj, A. Teologia i świętość. Translated by M. Jagodziński. Lublin 2010.

52. Trame, R. H. Rodrigo Sáncheza de Arévalo. Spanish dyplomat and champion of Papacy. Washington 1958.

53. Urban, M. "Hans Urs von Balthasar - otwarty rozum." In: H. U. von Balthasar, Pisma wybrane, Volume 1. Pisma filozoficzne. Translated by M. Urban, D. Jankowska. Kraków 2006, 5-17.

54. Vernant, J.-P. Źródła myśli greckiej. Translated by J. Szacki. Gdańsk 1996.

55. Waldenfels, H. O Bogu, Jezusie Chrystusie i Kościele - dzisiaj. Teologia fundamentalna w kontekście czasów obecnych. Translated by A. Paciorek. Katowice 1993.

56. Walicki, A. Marksizm i skok do królestwa wolności. Dzieje komunistycznej utopii. Warszawa 1996.

57. Węcławski, T. W teologii chodzi o ciebie. Przewodnik po źródtach i skutkach reologicznej wyobraźni. Kraków 1995.

58. Wojtkun, J. "Lumen fidei i Veritatis splendor - światło wiary w blasku prawdy moralnej." In: Perspektywy wiary. Edited by M. Jagodziński. Radom 2015, 143-163. 